\title{
The role of gut tissue in the energy metabolism of growing lambs fed forage or concentrate diets
}

\author{
Esther J. Finegan, Jock G. Buchanan-Smith* and Brian W. McBride \\ Department of Animal and Poultry Science, University of Guelph, Guelph, Ontario N1G 2W1, Canada
}

(Received 8 July 1998 - Revised 1 February 2001 - Accepted 14 March 2001)

\begin{abstract}
The role of the gastrointestinal tract (GIT) in explaining the less efficient utilization of metabolizable energy (ME) in growing lambs fed forage rather than concentrate-based diets was investigated by feeding forage (legume-grass silage) and concentrate (whole shelled maize) diets, at isoenergetic intakes (ME basis), using five groups of lambs. One group of seven lambs was an initial slaughter group and of the two groups (eight lambs per group) fed each diet, one group was fed for 8 weeks, whereas the other group was fed for 16 weeks. All lambs were slaughtered between 18.5 and $20 \mathrm{~h}$ following their last meal. Retained energy (as a percentage of ME intake) was higher (concentrate-fed 28 , forage-fed $17 ; P<0.001$ ) for the concentrate-fed animals. Weight-specific mucosal $\mathrm{O}_{2}$ uptake $(\mathrm{ml} / \mathrm{g}$ DM per $\mathrm{h})$, measured in vitro, was $37 \%$ higher for the forestomach (reticulum, rumen and omasum) and small intestine (jejunum) than for the abomasum and large intestine (caecum and colon), but there was no evidence for a diet effect (except colon; forage-fed 5.3, concentrate-fed 4.2; $P=0 \cdot 036$ ). Total GIT heat loss was estimated as 14 (forage-fed) and 18 (concentrate-fed) \% of the whole-body heat loss. Although the GIT did not contribute to increased thermogenesis in the forage-fed lambs in the present study, greater relative contribution of GIT tissue to whole-body mass, i.e. GIT as a percentage of empty-body weight(forage $7 \cdot 6$, concentrate $6 \cdot 6 ; P<0.001$ ) in the forage-fed animals supports a role for the GIT in contributing to higher thermogenesis observed in ruminants fed forage as opposed to concentrate diets.
\end{abstract}

\section{Gut energy metabolism: Forage: Concentrate}

When growing ruminants are fed the same amount of metabolizable energy (ME) as either forage or concentrate, the ME is used less efficiently, with more energy being lost as heat, on the forage diet (Orskov \& MacLeod, 1990). Initially, it was suggested (McClymont, 1952; Armstrong \& Blaxter, 1957) that inefficient utilization of acetate, a rumen fermentation end product produced in higher molar proportions by forage- than by concentrate-fed animals, might explain the higher heat increment associated with forage feeding. Subsequent respiration calorimetry (Orskov et al. 1969, 1979, 1991; Johnson, 1972; Orskov \& MacLeod, 1993) and comparative slaughter trials (Bull et al. 1970) have not supported this theory. More recently, enhanced metabolic activity of gut tissue in forage-fed animals has been considered as a potential contributor to high thermogenesis (Reynolds et al. 1991). As there are no currently published data that describe the comparative metabolic activity of all seven major gastrointestinal tract (GIT) components in ruminants fed forage or concentrate diets, the objective of the present study was to investigate the metabolic activity (weight-specific $\mathrm{O}_{2}$ consumption) of mucosal tissue from each of these GIT components.

\section{Methods \\ Experimental design}

This comparative slaughter trial was designed as a randomized complete block experiment, using two diets (forage and concentrate) and two feeding durations ( 8 and 16 weeks) in a $2 \times 2$ factorial treatment design. Each of the four treatments was replicated with eight animals, and an initial slaughter group was replicated with seven animals. The trial was carried out as two blocks, with the two groups of lambs born 3 months apart.

\section{Animals}

After weaning, the Rideau Arcott (Ainsworth et al. 1990) wether lambs were allowed to adjust to the change in

\footnotetext{
Abbreviations: GIT, gastrointestinal tract; ME, metabolizable energy.

* Corresponding author: Professor Jock G. Buchanan-Smith, fax +1 519836 9873, email jbs@aps.uoguelph.ca
} 
environment, for 3-4 weeks before introduction of the experimental diets. Animals were housed in pairs, with one forage- and one concentrate-fed lamb in each pen. Each animal was weighed weekly throughout the trial, and on each of the $2 \mathrm{~d}$ preceding slaughter, with weights being recorded at 14.00 hours.

\section{Diets and feeding}

The forage diet was based on mixed (legume-grass) silage, and the concentrate diet was based on whole shelled maize (Zea mays indentata). The silage, which was made from first-growth wilted forage, cut in the early bloom stage of development, consisted mainly of lucerne (Medicago sativa) with a small amount of grass, mostly timothy (Phleum pratense). The silage contained $393 \mathrm{~g} \mathrm{DM} / \mathrm{kg}$ and the composition ( $\mathrm{g} / \mathrm{kg} \mathrm{DM}$ ) was: organic matter 923, crude protein $\left(\mathrm{N}_{\text {total }} \times 6 \cdot 25\right) 183\left(\mathrm{~g} / \mathrm{kg}\right.$ total $\mathrm{N} ; \mathrm{NH}_{3}-\mathrm{N} 126$, nonprotein $\mathrm{N} 580$, soluble $\mathrm{N} 601$ ), lactic acid 63, acetic acid $11 \cdot 3$, propionic acid $0 \cdot 1$, butyric acid $0 \cdot 2$, neutral-detergent fibre 475, acid-detergent fibre 366, acid-detergent-fibre lignin 60 , with $\mathrm{pH} 4 \cdot 5$. The silage was supplemented with pellets containing maize-gluten meal, blood meal and a vitamin-mineral mix, and the maize was supplemented with pellets containing soyabean meal, maize-gluten meal, blood meal, urea and a vitamin-mineral mix (Table 1). The supplementary pellets were formulated so that lambs on the forage diet would be provided with equivalent amounts of rumen-undegradable crude protein to those of animals fed concentrate. The crude protein content of both diets was decreased by $3 \%$ after the first 8 weeks, to reflect modified protein requirements with increasing animal live weight (National Research Council, 1985).

Each animal was fed individually isoenergetic (ME basis) amounts of the diets with half their daily allotment given between 08.00 and 10.00 hours and the remainder between 14.00 and 16.00 hours. Diets were introduced gradually within the first 3 weeks of the trial, by replacing 25, 50, 75 and finally $100 \%$ of the creep feed to which the lambs were adapted during the pre-trial period. At the start of the trial, the lambs were grouped by $5 \mathrm{~kg}$ body-weight intervals. Intake limitations were reached first by those lambs fed the forage diet. To establish equivalent intakes of ME between diets, forage-fed animals were fed ad libitum, whereas concentrate-fed animals were restricted to a ME intake equivalent to that of forage-fed lambs in the same weight group. Water was available to all lambs at all times.

Total faeces were collected daily for a $7 \mathrm{~d}$ period, during week 12 of the 16 week feeding trial, using faecal collection bags. ME was calculated as digestible energy $\times 0.82$ for the forage-fed animals (National Research Council, 1985), and as digestible energy $\times 0.90$ for those fed concentrate, using the higher ratio reported by Johnson (1972) for growing lambs fed a whole-maize diet.

\section{Slaughter procedures and carcass sampling}

Initial-slaughter-group animals, which had been fed only the creep feed used during the pre-trial period, were slaughtered during week 1 of the feeding trial. Animals fed either the forage or concentrate diet for 8 weeks were slaughtered during week 9 and animals fed for 16 weeks were

Table 1. Diet composition for four groups of eight growing lambs

\begin{tabular}{|c|c|c|c|c|}
\hline \multirow{2}{*}{$\begin{array}{l}\text { Diet... } \\
\text { Feeding period... }\end{array}$} & \multicolumn{2}{|c|}{ Forage } & \multicolumn{2}{|c|}{ Concentrate } \\
\hline & Weeks 1-8 & Weeks 9-16 & Weeks 1-8 & Weeks 9-16 \\
\hline \multicolumn{5}{|l|}{ Ingredients (g/kg DM) } \\
\hline Lucerne silage & 882 & 938 & - & - \\
\hline Whole shelled maize & - & - & 500 & 500 \\
\hline Supplementary pellets & 118 & 62 & 500 & 500 \\
\hline Ground maize & - & - & 226 & 290 \\
\hline Maize-gluten meal & 59 & 25 & 77 & 36 \\
\hline Blood meal & 39 & 17 & 51 & 24 \\
\hline Soyabean meal & - & - & 69 & 70 \\
\hline Urea & - & - & 5 & 5 \\
\hline Limestone & - & - & 34 & 38 \\
\hline Dicalcium phosphate & - & - & 8 & 9 \\
\hline Vitamin-mineral mix* & 17 & 18 & 24 & 24 \\
\hline Fat & 3 & 2 & 6 & 4 \\
\hline \multicolumn{5}{|l|}{ Composition } \\
\hline DM (g/kg fresh weight) & 419 & 408 & 886 & 885 \\
\hline Organic matter (g/kg DM) & 918 & 914 & 942 & 928 \\
\hline Crude protein $†$ & 234 & 205 & 223 & 193 \\
\hline Gross energy (MJ/kg DM) & 18.92 & $18 \cdot 67$ & 19.09 & 18.51 \\
\hline $\mathrm{Ca}(\mathrm{g} / \mathrm{kg} \mathrm{DM})$ & 14 & 15 & 19 & 24 \\
\hline$P(g / k g D M)$ & 7 & 7 & 7 & 9 \\
\hline
\end{tabular}

*Vitamin-mineral mix contained (g/kg DM): MV700 (Masterfeeds, Maple Leaf Mills Limited, London, Ontario, Canada) 904, $\mathrm{CaSO}_{4} \cdot 2 \mathrm{H}_{2} \mathrm{O} 95, \mathrm{Na}_{2} \mathrm{MoO}_{4} \cdot 2 \mathrm{H}_{2} \mathrm{O}$ 1: MV700 contained (g/kg DM): Ca 150, P 100, NaCl 310, $\mathrm{Na} 120$, Fe 6.5, S 6, Fl 1.4, Mn 0.6, Zn 0.6, I $20 \mathrm{mg}$, Se $8 \mathrm{mg}$, Co $5 \mathrm{mg}$, vitamin A $30 \mathrm{mg}$, vitamin D $250 \mu \mathrm{g}$ vitamin E $200 \mathrm{mg}$.

†Rumen undegradability (g/kg crude protein) estimated from National Research Council (1989) as 371, 297, 513 and 432 for forage (1-8 weeks), forage (9-16 weeks), concentrate (1-8 weeks) and concentrate (916 weeks) diets respectively. 
slaughtered during week 17. For slaughter, animals were stunned by captive bolt, followed by exsanguination. Two animals, from the same pen, transported together with a third companion sheep, were slaughtered daily (two initialslaughter animals, or one fed forage for 8 weeks and one fed concentrate for 8 weeks, or one fed forage for 16 weeks and one fed concentrate for 16 weeks), with last feeding the previous afternoon (14.00-16.00 hours), and water available up to time of transport ( 08.30 hours, transport duration $20 \mathrm{~min})$. The times of slaughter (09.30 and 11.00 hours) were staggered by $1.5 \mathrm{~h}$, with half the forage-fed animals being randomly selected for slaughter at the earlier time (09.30 hours). Immediately following slaughter and exsanguination, carcasses were dressed, with the complete GIT being removed to facilitate immediate excision of samples for measurement of metabolic activity. All emptybody component samples were stored sealed and frozen until prepared for analysis by autoclaving of the frozen samples directly from the freezer, followed by homogenization, lyophilization and final grinding of the lyophilate, to provide dry ground homogenates from bony and soft, carcass and non-carcass components.

\section{Gastrointestinal tract tissue metabolic activity}

Samples $\left(36 \mathrm{~cm}^{2}\right)$ from each GIT component (reticulum, rumen (ventral sac), omasum (laminal free-edge sections, away from the omasal pillar), abomasum, small intestine (jejunum), caecum and colon) were removed from the carcass immediately following slaughter. These samples were washed with, and placed in fresh, ice-cold KrebsHenseleit buffer, for transport to the laboratory, where measurement of metabolic activity started within $30 \mathrm{~min}$ of slaughter. Mucosal tissue samples from each GIT component (reticulum (from outer edges of primary mucosal crests), rumen (one or more papillae), omasum (double-sided, from thin outer edges of laminae), abomasum, jejunum (representative of the small intestine), caecum and colon, as well as muscularis tissue samples (rumen only), $15-30 \mathrm{mg}$ fresh weight (two replicates from each GIT component)) were dissected under $\times 10$ magnification, then blotted dry and weighed, before being placed in M199 medium (Sigma Chemical, St Louis, MO, USA) before $\mathrm{O}_{2}$ uptake analysis. In vitro $\mathrm{O}_{2}$ uptake was measured polarographically using a YSI (Yellow Springs Instruments Inc., Yellow Springs, OH, USA) Clark-style $\mathrm{O}_{2}$ electrode. The tissues were maintained in $4 \mathrm{ml} \mathrm{M} 199$ medium at $\mathrm{pH}$ 7.4 and $37^{\circ} \mathrm{C}$ during measurement of $\mathrm{O}_{2}$ uptake for $10 \mathrm{~min}$. Larger fresh-weight samples of reticulum (600-800 mg), rumen $(300-800 \mathrm{mg})$, jejunum $(15-70 \mathrm{mg})$ and colon $(30-$ $80 \mathrm{mg}$ ) were dissected into mucosa and muscularis under $\times$ 10 magnification to determine the DM proportion of mucosa and muscularis in the GIT components sampled.

\section{Chemical analyses}

DM was determined by oven drying (Association of Official Analytical Chemists, 1990). Silage DM was determined by oven drying (Association of Official Analytical Chemists, 1990) and corrected for loss of volatile compounds (Dulphy \& Demarquilly, 1981; Galletti \& Piccaglia, 1988). Samples were analysed for ash using a muffle furnace, for crude protein by automatic Kjeldahl $\mathrm{N}$ analysis, for energy content by bomb calorimetry, for total fats by diethyl ether extraction, for $\mathrm{Ca}$ by atomic absorption spectrophotometry, and for $\mathrm{P}$ by autoanalyser (Association of Official Analytical Chemists, 1990). Analyses for neutral-detergent fibre, acid-detergent fibre and acid-detergent-fibre-lignin involved methods described by Robertson \& Van Soest (1981). Characterization of silage samples was carried out to determine $\mathrm{pH}$ and soluble $\mathrm{N}$ (Buchanan-Smith \& Yao, 1981), non-protein N (Buchanan-Smith \& Yao, 1978), lactic acid (Barker \& Summerson, 1941; Hadzija, 1974) and $\mathrm{NH}_{3}-\mathrm{N}$ (Novozamsky et al. 1974). Volatile fatty acid analysis for silage samples was by GC (Okeke et al. 1983).

\section{Statistical analyses}

Data were analysed using a general linear model procedure, with diet, duration and block specified in the CLASS statement as discrete, independent variables (SAS Institute Inc., 1989).

The model is given as:

$$
\mathrm{Y}_{\mathrm{ijk}}=\mu+\mathrm{D}_{\mathrm{i}}+\mathrm{L}_{\mathrm{j}}+(\mathrm{DL})_{\mathrm{ij}}+\mathrm{B}_{\mathrm{k}}+\varepsilon_{\mathrm{ijk}},
$$

where $\mathrm{D}$ is diet, $\mathrm{L}$ is duration, $\mathrm{B}$ is block, $(\mathrm{DL})$ is $\mathrm{D} \times \mathrm{L}$ interaction and $\mathrm{i}$ is $1-2, \mathrm{j}$ is $1-2$ and $\mathrm{k}$ is $1-2$. $\varepsilon$ is error, where $\varepsilon_{\mathrm{ijk}} \sim \mathrm{N}\left(0, \sigma^{2}\right)$; that is, $\varepsilon$ is random, normally (N) distributed, with mean of zero (0), and constant variance $\left(\sigma^{2}\right)$. Results are presented as the arithmetic means with their standard errors, for each of the four treatments. Results were considered significant when the probability of a significant difference was $P \leq 0 \cdot 05$.

\section{Results}

Performance and final body composition of the four groups of lambs and their feed utilization are shown in Table 2. As designed, DM intake of the forage-fed lambs was higher than that of the concentrate-fed lambs, in order to equalize $\mathrm{ME}$ intakes. However, ME intakes of the forage-fed lambs were higher than those of the concentrate-fed lambs, which was a result of a lower than expected digestibility (DM digestibility: forage $0 \cdot 55$, concentrate 0.58 ), hence calculated metabolizability, for the concentrate diet. Although live-weight gains achieved by lambs on both diets were similar, rates of empty body energy gains (empty-body gain $(\mathrm{MJ} / \mathrm{d})$ : forage-fed 1.01 , concentrate-fed $1.59, P<0.001)$ were greater for the lambs fed concentrate compared with those for lambs fed forage. Hence, lambs on the concentrate diet retained $0 \cdot 28$ of their ME intake in their empty-body gain compared with only 0.17 of the ME intake for lambs fed forage. The GIT accounted for 0.076 of the final emptybody weight in forage-fed lambs compared with a corresponding value of only $0.066(P<0.001)$ in lambs fed concentrate. Lambs fed concentrate consumed less crude protein than those fed forage, and this finding reflected the fact that the forage-fed diet was based on lucerne silage, which was high in total protein and rumendegradable protein. Lambs fed both diets for 16 weeks ate more DM and energy per d during the trial, compared with 
Table 2. Performance of growing lambs fed forage or concentrate diets for 8 or 16 weeks* (Mean values with their standard errors for eight lambs per treatment group)

\begin{tabular}{|c|c|c|c|c|c|c|c|}
\hline \multirow{2}{*}{$\begin{array}{l}\text { Diet }(D) \ldots \\
\text { Feeding period }(L) \ldots\end{array}$} & \multicolumn{2}{|c|}{ Forage } & \multicolumn{2}{|c|}{ Concentrate } & \multicolumn{3}{|c|}{$\begin{array}{l}\text { Statistical significance }(P) \text { of } \\
\text { effect of: }\end{array}$} \\
\hline & Weeks 1-8 & Weeks $1-16$ & Weeks $1-8$ & Weeks $1-16$ & $\mathrm{D}$ & $\mathrm{L}$ & $D \times L$ \\
\hline Initial live wt (kg fresh wt): Mean & $26 \cdot 86$ & $25 \cdot 80$ & $26 \cdot 46$ & $25 \cdot 17$ & 0.75 & 0.471 & 0.945 \\
\hline SE & $2 \cdot 11$ & 1.48 & $1 \cdot 12$ & 1.51 & & & \\
\hline Initial EB wt (kg fresh wt): Mean & 21.59 & $20 \cdot 74$ & $21 \cdot 29$ & $20 \cdot 22$ & 0.75 & 0.463 & 0.931 \\
\hline SE & 1.51 & $1 \cdot 20$ & 0.96 & $1 \cdot 16$ & & & \\
\hline \multicolumn{8}{|l|}{ Feed intake } \\
\hline DM (g/d per kg W $\left.\mathrm{W}^{0.75}\right): \underset{S E}{\text { Mean }}$ & $\begin{array}{r}54.90 \\
1.35\end{array}$ & $\begin{array}{r}59.53 \\
1.83\end{array}$ & $\begin{array}{r}44.62 \\
0.79\end{array}$ & $\begin{array}{r}47 \cdot 22 \\
1 \cdot 22\end{array}$ & $<0.001$ & 0.007 & 0.414 \\
\hline ME $\left(\mathrm{kJ} / \mathrm{d}\right.$ per $\left.\mathrm{kg} \mathrm{W}^{0.75}\right)$ : Mean & $452 \cdot 84$ & 486.05 & 431.49 & $456 \cdot 70$ & 0.025 & 0.011 & 0.711 \\
\hline SE & $11 \cdot 18$ & 14.95 & 7.66 & 11.81 & & & \\
\hline CP $\left(\mathrm{g} / \mathrm{d}\right.$ per kg $\left.\mathrm{W}^{0.75}\right)$ : Mean & $12 \cdot 50$ & 12.96 & $9 \cdot 67$ & $9 \cdot 84$ & $<0.001$ & 0.226 & 0.566 \\
\hline SE & 0.32 & 0.39 & $0 \cdot 17$ & $0 \cdot 18$ & & & \\
\hline \multicolumn{8}{|l|}{ Wt gain } \\
\hline Live wt gain (g fresh wt/d): Mean & $161 \cdot 1$ & $144 \cdot 2$ & $161 \cdot 1$ & $157 \cdot 2$ & 0.557 & 0.349 & 0.555 \\
\hline SE & $14 \cdot 2$ & $13 \cdot 1$ & $9 \cdot 0$ & 9.5 & & & \\
\hline EB gain (g fresh wt/d): Mean & $101 \cdot 2$ & $94 \cdot 6$ & $126 \cdot 0$ & $127 \cdot 6$ & 0.001 & 0.748 & 0.597 \\
\hline SE & $6 \cdot 9$ & 9.9 & $8 \cdot 1$ & $6 \cdot 0$ & & & \\
\hline \multicolumn{8}{|l|}{ Final empty body composition } \\
\hline Energy (kJ/kg EB fresh wt): Mean & $9034 \cdot 7$ & $9202 \cdot 6$ & $10808 \cdot 2$ & $11468 \cdot 5 \dagger$ & $<0.001$ & 0.399 & 0.632 \\
\hline SE & $481 \cdot 1$ & $538 \cdot 4$ & $396 \cdot 9$ & $481 \cdot 1$ & & & \\
\hline GIT (\% EB fresh wt): Mean & $7 \cdot 48$ & 7.69 & $6 \cdot 81$ & $6 \cdot 37$ & $<0.001$ & 0.659 & 0.215 \\
\hline SE & 0.25 & $0 \cdot 32$ & 0.22 & 0.20 & & & \\
\hline
\end{tabular}

EB, empty body; ME, metabolizable energy; $\mathrm{CP}$, crude protein $\left(\mathrm{N}_{\text {total }} \times 6.25\right)$; $\mathrm{W}^{0.75}$, metabolic body weight (live weight $\left.{ }^{0.75}\right)$; GIT, gastrointestinal tract $($ mesenteric and omental fat excluded).

${ }^{*}$ For details of diets and procedures, see Table 1 and p. 258.

$\dagger n 7$.

those fed for only 8 weeks, but demonstrated very little difference in rates of live or empty-body gain.

The contribution of component segments of the gut to the total GIT indicated no differences between concentrate- and forage-fed animals or between those fed the diets for only 8 weeks as opposed to 16 weeks (Table 3). Thus, increased proportional GIT weight in lambs as a result of feeding forage appears to have reflected itself in all components of the GIT.

The GIT is made up of layers of smooth muscle (muscularis) lined with mucosal tissue (mucosa). Metabolic activity, as in vitro $\mathrm{O}_{2}$ uptake of the inner mucosal layer, was measured immediately after slaughter for each component of the GIT (Table 4). The colon was the only

Table 3. Gastrointestinal tract (GIT) composition at slaughter for growing lambs fed forage or concentrate diets for 8 or 16 weeks ${ }^{*}$ (Mean values with their standard errors for eight lambs per treatment group)

\begin{tabular}{|c|c|c|c|c|c|c|c|}
\hline \multirow{2}{*}{$\begin{array}{l}\text { Diet }(\mathrm{D}) \ldots \\
\text { Feeding period }(\mathrm{L}) \ldots\end{array}$} & \multicolumn{2}{|c|}{ Forage } & \multicolumn{2}{|c|}{ Concentrate } & \multicolumn{3}{|c|}{$\begin{array}{c}\text { Statistical significance }(P=) \\
\text { of effect of: }\end{array}$} \\
\hline & Weeks 1-8 & Weeks 1-16 & Weeks 1-8 & Weeks $1-16$ & $\mathrm{D}$ & L & $\mathrm{D} \times \mathrm{L}$ \\
\hline \multicolumn{8}{|c|}{$\begin{array}{l}\text { GIT gross anatomical composition (g } \\
\text { fresh wt } / \mathrm{kg} \text { GIT fresh wt) }\end{array}$} \\
\hline Reticulum: Mean & $62 \cdot 3$ & $60 \cdot 9$ & $63 \cdot 4$ & $65 \cdot 5$ & 0.332 & 0.915 & 0.541 \\
\hline SE & $2 \cdot 7$ & 2.5 & $4 \cdot 3$ & 3.5 & & & \\
\hline Rumen: Mean & $352 \cdot 7$ & 348.1 & 334.1 & $346 \cdot 2$ & 0.221 & 0.65 & 0.32 \\
\hline SE & 9.5 & $9 \cdot 3$ & $5 \cdot 7$ & $13 \cdot 3$ & & & \\
\hline Omasum: Mean & $60 \cdot 0$ & $55 \cdot 3$ & $51 \cdot 2$ & 54.4 & 0.175 & 0.831 & 0.269 \\
\hline SE & $2 \cdot 6$ & $2 \cdot 2$ & $4 \cdot 3$ & 3.5 & & & \\
\hline Abomasum: Mean & $72 \cdot 2$ & $74 \cdot 2$ & $82 \cdot 2$ & $75 \cdot 4$ & 0.23 & 0.602 & 0.342 \\
\hline SE & $2 \cdot 2$ & $3 \cdot 3$ & 7.5 & $1 \cdot 7$ & & & \\
\hline Small intestine: Mean & $266 \cdot 5$ & $274 \cdot 1$ & $290 \cdot 5$ & $277 \cdot 4$ & 0.128 & 0.755 & 0.246 \\
\hline SE & $7 \cdot 1$ & 8.5 & $13 \cdot 1$ & $14 \cdot 3$ & & & \\
\hline Caecum: Mean & $67 \cdot 8$ & 63.5 & $67 \cdot 2$ & $58 \cdot 1$ & 0.47 & $0 \cdot 115$ & 0.562 \\
\hline SE & 3.5 & $4 \cdot 1$ & 4.2 & 4.2 & & & \\
\hline Colon: Mean & $118 \cdot 4$ & 123.9 & 111.4 & $122 \cdot 9$ & 0.61 & 0.285 & 0.695 \\
\hline SE & $10 \cdot 2$ & $9 \cdot 0$ & 4.5 & $7 \cdot 4$ & & & \\
\hline
\end{tabular}

* For details of diets and procedures, see Table 1 and p. 258. 
Table 4. Oxygen uptake by gastrointestinal mucosal tissue ( $\mathrm{ml}$ oxygen/g DM per $\mathrm{h}$ ) for growing lambs fed forage or concentrate diets for 8 or 16 weeks*

(Mean values with their standard errors for eight lambs per treatment group, except the group fed concentrates for 8 weeks where values are for seven lambs)

\begin{tabular}{|c|c|c|c|c|c|c|c|c|}
\hline \multirow{2}{*}{$\begin{array}{l}\text { Diet }(D) \ldots \\
\text { Feeding period }(L) \ldots\end{array}$} & \multicolumn{2}{|c|}{ Forage } & \multicolumn{2}{|c|}{ Concentrate } & \multirow[b]{2}{*}{ Mean } & \multicolumn{3}{|c|}{$\begin{array}{c}\text { Statistical significance }(P=) \\
\text { of effect of: }\end{array}$} \\
\hline & Weeks 1-8 & Weeks $1-16$ & Weeks 1-8 & Weeks 1-16 & & $\mathrm{D}$ & L & $D \times L$ \\
\hline Reticulum: Mean & 7.54 & $5 \cdot 30$ & 4.38 & $5 \cdot 14$ & $5 \cdot 59$ & 0.135 & 0.457 & 0.177 \\
\hline SE & 1.96 & 0.34 & 0.25 & 0.28 & & & & \\
\hline Rumen: Mean & $6 \cdot 33$ & $6 \cdot 86$ & $5 \cdot 61$ & $6 \cdot 49$ & $6 \cdot 32$ & $0 \cdot 189$ & 0.086 & 0.696 \\
\hline SE & 0.52 & 0.55 & 0.29 & 0.60 & & & & \\
\hline Omasum: Mean & $7 \cdot 56$ & $5 \cdot 66$ & $6 \cdot 88$ & $5 \cdot 82$ & $6 \cdot 48$ & 0.74 & 0.039 & 0.58 \\
\hline SE & 0.90 & 0.41 & 0.47 & 0.76 & & & & \\
\hline Abomasum: Mean & $4 \cdot 14$ & $4 \cdot 78$ & 4.88 & 4.55 & 4.59 & 0.568 & 0.679 & 0.261 \\
\hline SE & 0.44 & 0.25 & 0.39 & 0.47 & & & & \\
\hline Jejunum: Mean & 7.56 & $6 \cdot 00$ & $6 \cdot 47$ & $6 \cdot 55$ & $6 \cdot 65$ & 0.758 & 0.206 & 0.244 \\
\hline SE & 0.57 & 0.81 & 0.50 & 0.77 & & & & \\
\hline Caecum: Mean & 4.79 & $4 \cdot 86$ & $4 \cdot 74$ & 4.08 & $4 \cdot 62$ & $0 \cdot 385$ & 0.406 & 0.316 \\
\hline SE & 0.51 & 0.46 & 0.41 & 0.40 & & & & \\
\hline Colon: Mean & $5 \cdot 77$ & 4.85 & 3.66 & 4.63 & 4.73 & 0.036 & 0.983 & 0.085 \\
\hline SE & 0.69 & 0.54 & 0.31 & 0.27 & & & & \\
\hline Rumen (muscularis): Mean & $2 \cdot 32$ & $2 \cdot 56$ & $2 \cdot 28$ & $2 \cdot 57$ & $2 \cdot 43$ & 0.972 & $0 \cdot 236$ & 0.925 \\
\hline SE & $0 \cdot 18$ & 0.26 & 0.21 & 0.22 & & & & \\
\hline
\end{tabular}

* For details of diets and procedures, see Table 1 and p. 258.

GIT component for which a significant diet effect $(P=$ 0.036 ) was observed, with greater activity noted for the forage- compared with the concentrate-fed lambs. There were no effects of length of feeding period on $\mathrm{O}_{2}$ consumption of GIT tissue with the exception of the omasum, which had significantly less activity $(P=0 \cdot 039)$ in lambs that had been fed longer and were older than those on the diets for only 8 weeks. Overall, for animals from all treatment groups, four components of the GIT (reticulum, rumen, omasum and jejunum) demonstrated consistently greater $\mathrm{O}_{2}$ consumption activity than other GIT components (abomasum, caecum, colon). There was no effect of diet or length of feeding period on $\mathrm{O}_{2}$ consumption in muscularis tissue taken from the rumen.

Total $\mathrm{O}_{2}$ uptake by GIT tissue was calculated on the basis of the proportions of mucosa and muscularis measured for reticulum, rumen, jejunum and colon (Table 5), and on estimates for the remaining GIT components. There were no significant effects of either diet or feeding period on proportions of mucosa in reticulum, rumen, jejunum and colon (Table 5). To estimate the proportions of mucosa and muscularis in abomasal and caecal tissue, mean values for the jejunum and colon respectively were used. For the omasum, a value of 0.25 was chosen for the proportion of mucosa, since use of this value resulted in the total omasal mucosa having an $\mathrm{O}_{2}$ uptake of $8.9 \%$ of the total rumen mucosa. Hofmann (1988) had observed that ovine omasal mucosa had only $10 \%$ of the absorptive capacity of rumen mucosa. Values for weight-specific $\mathrm{O}_{2}$ uptake for mucosal tissues from all GIT components were taken

Table 5. Mucosal tissue (DM) as a proportion of total (mucosa plus muscularis) tissue in some gastrointestinal components following slaughter of growing lambs fed forage or concentrate diets for 8 or 16 weeks*

(Mean values with their standard errors for eight lambs per treatment group)

\begin{tabular}{|c|c|c|c|c|c|c|c|c|}
\hline \multirow{2}{*}{$\begin{array}{l}\text { Diet }(D) \ldots \\
\text { Feeding period }(L) \ldots\end{array}$} & \multicolumn{2}{|c|}{ Forage } & \multicolumn{2}{|c|}{ Concentrate } & \multirow[b]{2}{*}{ Mean } & \multicolumn{3}{|c|}{$\begin{array}{l}\text { Statistical significance }(P=) \\
\text { of effect of: }\end{array}$} \\
\hline & Weeks $1-8$ & Weeks 1-16 & Weeks 1-8 & Weeks $1-16$ & & $D$ & L & $D \times L$ \\
\hline Reticulum: Mean & $0.42 \dagger$ & $0.41 \ddagger$ & $0.45 \dagger$ & $0.47 \S$ & 0.44 & $0 \cdot 856$ & 0.512 & 0.414 \\
\hline SE & 0.06 & 0.03 & 0.03 & 0.04 & & & & \\
\hline Rumen: Mean & 0.44 & 0.47 & 0.48 & 0.55 & 0.48 & 0.112 & 0.199 & 0.631 \\
\hline SE & 0.04 & 0.03 & 0.04 & 0.04 & & & & \\
\hline Jejunum: Mean & 0.68 & $0.74 \ddagger$ & $0.75 \|$ & $0.73 \|$ & 0.72 & 0.82 & 0.671 & 0.616 \\
\hline SE & 0.08 & 0.04 & 0.08 & 0.09 & & & & \\
\hline Colon: Mean & 0.59 & 0.57 & 0.61 & 0.55 & 0.58 & 0.966 & 0.413 & 0.785 \\
\hline SE & 0.05 & 0.04 & 0.07 & 0.04 & & & & \\
\hline
\end{tabular}

* For details of diets and procedures, see Table 1 and p. 258.

$\dagger n 4$.

$\ddagger n 6$.

$\$ n 5$.

|| $n 7$. 
from Table 4, with the value measured for rumen muscularis tissue being used as an estimate of activity in muscularis tissue from all other GIT components. Based on these calculations, weight-specific $\mathrm{O}_{2}$ consumption on a DM basis (ml/g DM per h) was estimated to be GIT $4 \cdot 2$, foregut $4 \cdot 1$ and hindgut $4 \cdot 3$. The weight-specific $\mathrm{O}_{2}$ uptake $(\mathrm{ml} / \mathrm{g}$ DM per $\mathrm{h})$ for each GIT component (mucosal+ muscularis tissues) was estimated to be reticulum $3 \cdot 5$, rumen $4 \cdot 3$, omasum $3 \cdot 4$, abomasum $3 \cdot 8$, small intestine 4.9 , caecum 3.8 and colon $3 \cdot 7$. The estimate of total $\mathrm{O}_{2}$ uptake by a GIT component, expressed as a proportion of total GIT uptake, was higher for the abomasum in concentrate-fed animals (forage-fed 0.08, concentrate-fed $0.10 ; P=0.035)$, and higher for the caecum when forage was fed (forage-fed 0.06, concentrate-fed 0.05; $P=0 \cdot 011$ ); all other components demonstrated no effect of diet, with values of reticulum $0 \cdot 05$, rumen $0 \cdot 32$, omasum $0 \cdot 04$, small intestine $0 \cdot 27$ and colon $0 \cdot 17$.

Using a value of $17 \cdot 15 \mathrm{~kJ} / \mathrm{l}$ as the heat equivalent for $\mathrm{O}_{2}$ consumption (Blaxter, 1989), it was possible in the present study to estimate the contribution of GIT tissue to total heat production. Total heat production was taken as the difference between $\mathrm{ME}$ intake and energy retention. Heat equivalent to $\mathrm{O}_{2}$ consumption by the GIT was estimated at 0.77 and $0.82 \mathrm{MJ} / \mathrm{d}$ in forage- and concentrate-fed animals respectively. Corresponding whole-body heat-loss estimates were 5.5 and $4.6 \mathrm{MJ} / \mathrm{d}$, hence the GIT represented 0.14 and $0 \cdot 18$ of the total for forage- and concentrate-fed animals respectively.

\section{Discussion}

Although the same ME intakes across groups were anticipated, actual ME intake of concentrate-fed lambs was lower than expected, owing to correspondingly low metabolizability of the concentrate diet. Further, the bulk of the forage diet and the twice daily feeding schedule restricted ME intakes of all lambs to only approximately twice the estimate of fasting heat production in sheep (Agriculture and Food Research Council, 1993). Thus, the amount of energy available for body-weight gain was limited. Despite these limitations, concentrate-fed lambs gained gross empty-body weight and energy at a greater rate than was observed with the forage-fed animals. Thus, the hypothesis for the present study of greater efficiency of ME utilization by concentrate- compared with forage-fed ruminants was confirmed.

Some of the effects observed for forage-fed lambs in the present study may have reflected their higher intake of crude protein, compared with those of lambs fed concentrate. This difference was caused by planning the diets so that the expected intakes of rumen-undegradable protein, hence amino acid supply through digestion, were similar across diets. Actual intakes of undegradable protein, calculated from the rumen-undegradability values from the National Research Council (1989) were 4.77 and 4.34 g/d per kg live weight $^{0.75}$ for lambs fed forage for 8 and 16 weeks respectively, compared with 5.13 and $4.64 \mathrm{~g} / \mathrm{d}$ per $\mathrm{kg}$ live weight $^{0.75}$ for lambs fed grain for 8 and 16 weeks respectively. Thus, the excess crude protein intake for the forage-fed lambs arose primarily through a higher intake of rumen-degradable protein in these lambs compared with those fed concentrate. Excessive intake of rumen-degradable protein would be expected to have metabolic implications, such as increased synthesis of urea by the liver, and protein metabolism in GIT tissue. However, the only indication of a diet effect on GIT protein metabolism (weight-specific in vitro $\mathrm{O}_{2}$ uptake $(\mathrm{ml} / \mathrm{g}$ DM per $\mathrm{h}$ ), mucosal tissue) in the present study was for the colon (forage $5 \cdot 31$, concentrate $4 \cdot 15 ; P=0 \cdot 036$ ). Further, excess intakes of rumen-degradable protein are often observed with ruminants consuming high-quality forage diets (Reynolds et al. 1991; Kelly et al. 1993a), and increased liver-driven thermogenesis could be a contributing factor to the higher than expected thermogenesis associated with these diets.

Although feeding a forage diet compared with a concentrate diet in the present study was associated with enhanced growth of the total mass of the GIT, no effects on weights of different GIT components, expressed as a proportion of the total, were observed. Both Bailey (1986), feeding cattle, and McLeod \& Baldwin (1998), feeding sheep, offered isoenergetic ME diets based on either forages or concentrates and demonstrated heavier omasa in the forage-fed animals, although the weights of the reticulorumen, abomasum and intestine were unaffected by diet.

Although no published data demonstrate the comparative metabolic activity of all seven major GIT components, previous studies have reported on the in vitro metabolic activity of bovine (Harmon et al. 1991; Kelly et al. 1991, $1993 a, 1995)$ and ovine (Burrin et al. 1990) rumen mucosa, bovine (McBride \& Milligan, 1984) and ovine (McBride \& Milligan, 1985; Kelly et al. 1993b) duodenal mucosa, and bovine (McBride et al. 1989) and ovine (Burrin et al. 1990) jejunum (combined mucosa and muscularis). These studies have demonstrated consistent values for DM weight-specific $\mathrm{O}_{2}$ uptake by mucosa of 6-9 $\mathrm{ml} / \mathrm{g}$ DM per $\mathrm{h}$, across species and ages, with the single reported value for muscularis (bovine rumen, $2.8 \mathrm{ml} / \mathrm{g}$ DM per h; Kelly et al. 1991) being only $36 \%$ of the corresponding mucosal value. The current study reports values of $5 \cdot 61-7.56 \mathrm{ml} \mathrm{O}_{2} / \mathrm{g}$ DM per $\mathrm{h}$ (Table 4) for rumen and jejunal mucosa, and values for rumen muscularis which are $39 \%$ of the rumen mucosal values. These values are consistent with those from previous studies.

Harmon et al. (1991) have also investigated the effect of feeding either forage or concentrate diets on the in vitro $\mathrm{O}_{2}$ uptake by rumen mucosal tissue. They fed either forage (lucerne hay) or concentrate (rolled wheat and sorghum, 50:50, w/w) at two net energy intake levels (maintenance and twice maintenance), in two daily meals, and reported no effect of diet on weight-specific in vitro $\mathrm{O}_{2}$ uptake. However, Harmon et al. (1991) reported significantly greater metabolic activity in the rumen mucosa of animals fed at twice maintenance $v$. maintenance. McLeod \& Baldwin (1998) also found no effect of isoenergetic intakes of forage- and concentrate-based diets on in vitro $\mathrm{O}_{2}$ uptake by mucosal cells isolated from the rumen, duodenum, jejunum and ileum. In the present study $\mathrm{O}_{2}$ consumption was higher in the mucosa from the colon of forage-fed compared with that of concentrate-fed lambs, but other tissues were not significantly affected. This response to diet in the colon mucosa may reflect increased intake of both fibre and protein. 
As observations of $\mathrm{O}_{2}$ consumption were made in the present study for all GIT segments, the results of these observations were integrated to obtain estimates of heat production in the entire GIT. The validity of this process was suggested by the fact that the estimate for the proportional contribution of the GIT to total heat production, of between 14 and $18 \%$, is comparable with other estimates of $18-28 \%$, based on in vivo measurements of $\mathrm{O}_{2}$ consumption by the entire portal-drained viscera (in sheep: 19-28\% Burrin et al. 1989, 18.5\% Thompson et al. 1978; in cattle: 18-25\% Huntington, 1990). Johnson et al. (1990), in their review of energy use by ruminant visceral organs, compared daily GIT $\mathrm{O}_{2}$ consumption determined using in vitro and in vivo techniques; the estimate of energy use of $1202 \mathrm{~J} / \mathrm{g}$ per d from in vitro studies compared closely with the estimate from in vivo studies of $1101 \mathrm{~J} / \mathrm{g}$ per $\mathrm{d}$. Although heat production in the GIT of forage- and concentrate-fed lambs in the present study could not be compared statistically, the estimates made in each group of animals (forage-fed $5.5 \mathrm{MJ} / \mathrm{d}$, concentrate-fed $4.6 \mathrm{MJ} / \mathrm{d}$ ) were close.

Reynolds et al. (1991) investigated energy expenditure by the entire portal-drained viscera (GIT, pancreas, spleen and mesenteric fat), and reported increased in vivo $\mathrm{O}_{2}$ consumption by the portal-drained viscera $(1 / \mathrm{h}$; forage-fed, 26.4 , concentrate-fed $20.9 ; P<0.05)$ when heifers were fed a forage diet (ground lucerne hay-ground maize 0 75:0·25, $\mathrm{w} / \mathrm{w}$ ) as opposed to a concentrate-based diet (ground maize-ground lucerne 0 75:0·25, w/w). Both diets, each fed at two isoenergetic ME intake levels (maintenance and twice maintenance), were ground and fed as pellets, with twelve equal daily meals being offered at $2 \mathrm{~h}$ intervals. If GIT mucosal $\mathrm{O}_{2}$ uptake, on a weight-specific basis, differed for concentrate- and forage-fed animals, such a difference might be more easily demonstrated in animals on a continuous feeding schedule, such as the twelve equal daily meals offered at $2 \mathrm{~h}$ intervals reported by Reynolds et al. (1991), rather than $18 \mathrm{~h}$ after the last meal, as in the current study. Kelly et al. (1993a) described the $24 \mathrm{~h}$ pattern of $\mathrm{O}_{2}$ consumption by the rumen mucosa in steers fed lucerne hay in a single daily feeding. $\mathrm{O}_{2}$ uptake increased by more than $20 \%$ during the $3 \mathrm{~h}$ meal period, and was still elevated $9 \mathrm{~h}$ after the meal ended, returning to premeal levels before the start of the meal on the following day (a pattern paralleled by the rumen concentration of acetate, propionate and butyrate). Harmon et al. (1991) found a significant effect of intake level $\left(\mathrm{O}_{2}\right.$ uptake $(\mathrm{nmol} / \mathrm{mg}$ per $\mathrm{h})$ net energy at maintenance $42 \cdot 3$, twice maintenance $53 \cdot 1 ; P<0 \cdot 01$ ) on $\mathrm{O}_{2}$ uptake by rumen mucosa taken from animals slaughtered following an overnight fast, but they did not demonstrate an effect of diet (lucerne hay, or wheat and sorghum) in the same experiment.

No evidence is presented from the present study for significantly higher metabolic activity in the mucosal gut tissues of the forage-fed animals (with the exception of the colon; $P=0.036$ ), but GIT tissue did represent a significantly higher proportion of total empty-body gain in these animals compared with that of animals fed a concentrate diet $(P<0 \cdot 01)$. As implied earlier, the fact that measurements of weight-specific $\mathrm{O}_{2}$ uptake were taken at approximately $18 \mathrm{~h}$ after the lambs were last fed may have prevented detection of greater effects of diet on metabolic activity that could have existed earlier after the last feeding or over an entire $24 \mathrm{~h}$ period. More measurements of $\mathrm{O}_{2}$ uptake, in vitro or in vivo, were beyond the scope of the present study. Although no large differences in estimated total energy expenditures of gut tissues from forage- and concentrate-fed lambs were found in the present study, the significant effect of diet on proportional weight of the GIT does not exclude a role for the GIT in the increased thermogenesis of ruminants fed forage diets as opposed to concentrate diets.

\section{Acknowledgements}

The authors acknowledge most gratefully, and with much pleasure, the considerable technical knowledge and experience invested in this project by Cheryl Campbell and Linda Trouten-Radford, and the most valuable and dependable support in so many areas of the project provided by Sandy Calder. Cathy Britton, Dave Hindley, Bev Livingston and Brant Mutter at the Eramosa Research Station made possible the exceptional daily care of the sheep throughout the feeding trial. This work was supported by funding from the Ontario Ministry of Agriculture, Food and Rural Affairs, and by research grants (J.G.B.S., B.W.M.) of the Natural Sciences and Engineering Research Council of Canada.

\section{References}

Agriculture and Food Research Council (1993) Energy and Protein Requirements of Ruminants. Wallingford, Oxon.: CAB International.

Ainsworth L, Heaney DP, Fiser PS, Langford GA, Shrestha JNB \& Leger DA (1990) Research and Technology for Increasing the Efficiency and Output of Lamb Production Systems. Technical Bulletin 1987-11E, Animal Research Centre Contribution 86-28, Ottawa, Ont.: Research Branch, Agriculture Canada.

Armstrong DG \& Blaxter KL (1957) The utilization of acetic, propionic and butyric acids by fattening sheep. British Journal of Nutrition 11, 413-425.

Association of Official Analytical Chemists (1990) Official Methods of Analysis, 15th ed., Washington, DC: AOAC.

Bailey CB (1986) Growth of digestive organs and their contents in Holstein steers: Relation to body weight and diet. Canadian Journal of Animal Science 66, 653-661.

Barker SB \& Summerson WH (1941) The colorimetric determination of lactic acid in biological material. Journal of Biological Chemistry 138, 535-545.

Blaxter K (1989) Energy Metabolism in Animals and Man. Cambridge: Cambridge University Press.

Buchanan-Smith JG \& Yao YT (1978) Non-protein nitrogen in corn silage: a partial characterization, its utilization in the rumen and effect upon digestibility and retention of nitrogen in lambs. Canadian Journal of Animal Science 58, 681-690.

Buchanan-Smith JG \& Yao YT (1981) Effect of additives containing lactic acid bacteria and/or hydrolytic enzymes with an antioxidant upon the preservation of corn or alfalfa silage. Canadian Journal of Animal Science 61, 669-680.

Bull LS, Reid JT \& Johnson DE (1970) Energetics of sheep concerned with the utilization of acetic acid. Journal of Nutrition 100, 262-276.

Burrin DG, Ferrell CL, Britton RA \& Bauer M (1990) Level of nutrition and visceral organ size and metabolic activity in sheep. British Journal of Nutrition 64, 439-448. 
Burrin DG, Ferrell CL, Eisemann JH, Britton RA \& Nienaber JA (1989) Effect of level of nutrition on splanchnic blood flow and oxygen consumption in sheep. British Journal of Nutrition 62 , 23-34.

Dulphy JP \& Demarquilly C (1981) Problemes particuliers aux ensilages (Problems specific to ensiled feeds). Prevision de la Valeur Nutritive des Aliments des Ruminants (Forecast of the Nutritive Value of Feeds for Ruminants), pp. 81-104. Versailles: INRA Publications.

Galletti GC \& Piccaglia R (1988) Water determination in silages by Karl Fischer titration. Journal of the Science of Food and Agriculture 43, 1-7.

Hadzija O (1974) A simple method for the quantitative determination of muramic acid. Analytical Biochemistry 60, $512-517$.

Harmon DL, Gross KL, Krehbiel CR, Kreikemeier KK, Bauer ML \& Britton RA (1991) Influence of dietary forage and energy intake on metabolism and acyl-CoA synthetase activity in bovine ruminal epithelial tissue. Journal of Animal Science 69 , 4117-4127.

Hofmann RR (1988) Anatomy of the gastro-intestinal tract. In The Ruminant Animal, pp. 250-268 [DC Church, editor]. Englewood Cliffs, NJ: Prentice Hall.

Huntington GB (1990) Energy metabolism in the digestive tract and liver of cattle: influence of physiological state and nutrition. Reproduction, Nutrition, Développement 30, 35-47.

Johnson DE (1972) Heat increment of acetate and corn and effects of casein infusions with growing lambs. Journal of Nutrition 102, 1093-1100.

Johnson DE, Johnson KA \& Baldwin RL (1990) Changes in liver and gastrointestinal tract energy demands in response to physiological workload in ruminants. Journal of Nutrition $\mathbf{1 2 0}$, 649-655.

Kelly JM, McBride BW \& Milligan LP (1993a) In vitro ouabainsensitive respiration and protein synthesis in ruminal epithelial papillae of Hereford steers fed either alfalfa or bromegrass hay once daily. Journal of Animal Science 71, 2799-2808.

Kelly JM, McBride BW, Milligan LP \& Waldo DR (1991) Oxygen consumption and the energy costs of $\mathrm{Na}^{+}, \mathrm{K}^{+}$-transport in the rumen of Holstein-Friesian steers. Proceedings of the New Zealand Society of Animal Production 51, 123-127.

Kelly JM, Southorn BG, Kelly CE, Milligan LP \& McBride BW (1993b) Quantification of in vitro and in vivo energy metabolism of the gastrointestinal tract of fed and fasted sheep. Canadian Journal of Animal Science 71, 855-868.

Kelly JM, Vaage AS, Milligan LP \& McBride BW (1995) In vitro ouabain-sensitive respiration and protein synthesis in rumen epithelial papillae of Hereford steers fed either timothy hay or timothy hay supplemented with cracked corn once daily. Journal of Animal Science 73, 3775-3784.

McBride BW, Early RJ \& Ball RO (1989) Protein synthesis and the energy costs of $\mathrm{Na}+, \mathrm{K}+$-transport in tissues of somatotropin treated steers. In Energy Metabolism of Farm Animals, European Association for Animal Production. Publication no. 43, pp. 107-111 [Y Van Der Honing and WH Close, editors]. Wageningen: Pudoc.

McBride BW \& Milligan LP (1984) The effect of lactation on ouabain-sensitive respiration of the duodenal mucosa of cows. Canadian Journal of Animal Science 64, 817-824.
McBride BW \& Milligan LP (1985) Influence of feed intake and starvation on the magnitude of $\mathrm{Na}+\mathrm{K}+$-ATPase (EC 3.6.1.3)dependent respiration in duodenal mucosa of sheep. British Journal of Nutrition 53, 605-614.

McClymont GL (1952) Specific dynamic action of acetic acid and heat increment of feeding in ruminants. Australian Journal of Scientific Research 5B, 374-383.

McLeod KR \& Baldwin VI (1998) Influence of energy density and metabolizable energy intake on visceral organ growth in sheep. In Energy Metabolism of Farm Animals. Proceedings of the 14th Symposium on Energy Metabolism, pp. 31-34 [KJ McCracken, EF Unsworth and ARG Wylie, editors]. Wallingford, Oxon.: CAB International.

National Research Council (1985) Nutrient Requirements of Sheep, 6th revised ed. Washington, DC: National Academy Press.

National Research Council (1989) Nutrient Requirements of Dairy Cattle, 6th revised ed. Washington, DC: National Academy Press.

Novozamsky J, Van Eck R, Van Schovwenburg JC \& Walinga I (1974) Total N determination in plant material by means of the indophenol blue method. Netherlands Journal of Agricultural Science 22, 3-5.

Okeke GC, Buchanan-Smith JG \& Grieve DR (1983) Effect of sodium bicarbonate on rate of passage and degradation of soybean meal in postpartum dairy cows. Journal of Dairy Science 66, 1023-1031.

Orskov ER, Flatt WP, Moe PW, Munson AW, Hemken RW \& Katz I (1969) The influence of ruminal infusion of volatile fatty acids on milk yield and composition and on energy utilization by lactating cows. British Journal of Nutrition 23, 443-453.

Orskov ER, Grubb DA, Smith JS, Webster AJF \& Corrigall W (1979) Efficiency of utilization of volatile fatty acids for maintenance and energy retention by sheep. British Journal of Nutrition 41, 541-551.

Orskov ER \& MacLeod NA (1990) Dietary induced thermogenesis and feed evaluation in ruminants. Proceedings of the Nutrition Society 49, 227-237.

Orskov ER \& MacLeod NA (1993) Effect of level of input of different proportions of volatile fatty acids on energy utilization in growing ruminants. British Journal of Nutrition 70, 679-687.

Orskov ER, MacLeod NA \& Nakashima Y (1991) Effect of different volatile fatty acid mixtures on energy metabolism in cattle. Journal of Animal Science 69, 3389-3397.

Reynolds CK, Tyrrell HF \& Reynolds PJ (1991) Effects of diet forage-to-concentrate ratio and intake on energy metabolism in growing beef heifers: whole body energy and nitrogen balance and visceral heat production. Journal of Nutrition 121, 994-1003.

Robertson JB \& Van Soest PJ (1981) The detergent system of analysis and its application to human foods. In The Analysis of Dietary Fiber in Food, pp. 123-158 [WTP James and O Theander, editors]. New York, NY: Marcel Dekker Inc.

SAS Institute Inc. (1989) SAS/STAT User's Guide, version 6, 4th ed. Cary, NC: SAS Institute Inc.

Thompson GE, Manson W, Clarke PL \& Bell AW (1978) Acute cold exposure and the metabolism of glucose and some of its precursors in the liver of the fed and fasted sheep. Quarterly Journal of Experimental Physiology 63, 189-199. 